\title{
On the Effects of Doing CDA Term Projects on Iranian Graduate TEFL Students' Critical Pedagogic Attitudes
}

\author{
Shaban Barimani Varani \\ Department of English Language, Islamic Azad University (I.A.U), Sari, Iran \\ Seyed Ahmad Kasaian \\ Department of English Language, Farhangian University, Dr. Shariati Campus, Sari, Iran
}

\begin{abstract}
The expansion of the scope of TESOL to include the social, political, and ideological aspects of the learners' lives, has necessitated a more systematic application of the principles of critical pedagogy to the field of ELT. Despite this, few attempts have been made in this regard. Having felt the need, the present researchers embarked on examining the effectiveness of assigning critical discourse analysis term projects to graduate students of TEFL as one of the many possible ways to promote the critical pedagogic attitudes of the prospective teachers of English as a foreign language. To this end, forty three homogenous male and female graduate students of TEFL studying at the Islamic Azad University, Mazandaran Science and Research Branch, took a five-point Likert-scale critical attitude questionnaire to show the level of their critical pedagogic attitudes. Then, the students in the experimental group were guided to choose Critical Discourse Analysis (CDA) topics for their term projects while the rest of the students who constituted the control group were guided to choose NCDA topics. In the third phase of the study, the subjects were given the same attitude questionnaire as the post-test in order to determine whether the subjects' critical attitudes had changed as a result of doing their term-projects. The results showed that doing critical pedagogy-related term projects had a significant influence on the critical pedagogic attitudes of the graduate students of TEFL. The implications of this finding are discussed in the present paper.
\end{abstract}

Index Terms - critical discourse analysis, critical pedagogy, critical pedagogic attitudes, doing term projects

\section{PRELIMINARIES}

If we are to envisage one worthwhile goal for education, that goal cannot be anything other than enabling individuals to understand themselves, their worlds and their people better. This, in turn, is possible through the development of critical thinking in the learners. Only a critical thinker is capable of "skillfully conceptualizing, synthesizing, and evaluating information gathered from, or generated by observation, experience, reflection, reasoning, or communication as a guide to belief and action" (Scriven and Paul 1996, p.40).

Critical thinking is a "positive process of calling into question the assumptions underlying our customary, habitual ways of thinking and acting and then being ready to think and act differently" (Brookfield 1987, p. 6). As Brookfield's (1987) definition clearly states, critical thinking is a process of examining and assessing the status quo with an attempt to improve it.

Although enabling individuals to see themselves, their worlds and their people critically does not seem to have many opponents, "the emphasis of most people's teaching has been on teaching content" (Fisher and Scriven 1997, p.2). This is, at least partly, attributable to the fact the implications of critical pedagogy which was introduced in 1960s by the Brazilian educator Paulo Freire (1921-1997) in his seminal book, "Pedagogy of the Oppressed", has not been fully appreciated by educators.

Rooted in critical theory, critical pedagogy asserts that education is political (Freire, 1970; Giroux, 1983; Freire \& Macedo, 1987; Pennycook, 1989; McLaren \& Kincheloe, 2007). One clear implication of critical pedagogy, among others, for education in general and the field of ELT as the most relevant discipline to the present study in particular, is that teachers must assume new identities and be ready to "develop counterhegemonic pedagogies that not only empower students by giving them the knowledge and social skills they will need to be able to function in the larger society as critical agents, but also educate them for transformative action" (1988, p. xxxiii).

There are several strategies to strengthen the critical attitudes of EFL learners. If educators in the field of ELT are convinced that education should aim at producing critical people, they should try a myriad of strategies to approach the problem. One possible way of making the prospective teachers critical can be involving them in doing critical discourse analysis term projects through which they have to do a lot of reading and review the related literature and be familiarized with the concepts and goals of critical pedagogy.

\section{A. Statement of the Problem}


Until recently, the main focus of educational activities in the field of TESOL was primarily on the promotion of learners' grammatical accuracy and communicative fluency (Kumaravadivelu, 2006). This was probably because scholars "tended to assume that teaching English was a politically neutral activity and that it would bring untold blessings to those who succeeded in learning it" (Richards, 2009, P.6). However, "[d]uring the 1990s", as Kumaravadivelu (2006, p.70) states, "the TESOL profession took a decidedly critical turn" which recognized "language as ideology, not just as system".

The expansion of the scope of TESOL to include the social, political, and ideological aspects of the learners' lives, necessitated the application of the principles of critical pedagogy to the field of ELT including foreign language teacher education. Despite the significance of the issue, few attempts have been done in this regard in the context of the Islamic Iran whose anti-imperialistic motives further justify the unraveling of the hidden agendas of the ELT industry. Having felt the need, the present researchers embarked on examining the effectiveness of assigning critical pedagogyrelated term projects to graduate students of TEFL as one of the many different attempts that one can do to promote the critical pedagogic attitudes of the prospective teachers of English as a foreign language.

\section{B. Research Question and Null Hypothesis}

In order to fulfill the aims of the present research, the following research question was posed:

$\mathbf{Q}_{1}$ : Does doing term projects in the area of critical discourse analysis affect the Iranian graduate TEFL students' critical pedagogic attitudes?

Based on the research question, the following null hypothesis was formulated:

$\mathbf{H}_{\mathbf{O} 1}$ : Doing term projects in the area of critical discourse analysis does not affect the Iranian graduate TEFL students' critical pedagogic attitudes.

\section{THEORETICAL BACKGROUND}

\section{A. Critical Pedagogy}

The concept of critical pedagogy is rooted in the principles of critical theory which is primarily focused on power relations in society and strives to generate justice by enabling people to free themselves from oppression. As Horkheimer (1982, p.244) states, a theory is critical if it seeks "to liberate human beings from the circumstances that enslave them". Critical pedagogy sees education as the way through which liberation of people from different forms of discrimination should be done. This function of critical pedagogy is manifest in Kellner's (2000, 197) statement: "critical pedagogy considers how education can provide individuals with the tools to better themselves and strengthen democracy, to create a more egalitarian and just society, and thus to deploy education in a process of progressive social change". The emergence of critical pedagogy was a response to the emerging forces of oppression. Critical pedagogy, therefore, tries "to raise questions about inequalities of power, about the false myths of opportunity and merit for many students, and about the way belief systems become internalized to the point where individuals and groups abandon the very aspiration to question or change their lot in life" (Burbules \& Burk, 1999). According to Kanpol (1999, p. 27), "critical pedagogy seeks to unoppress the oppressed and unite people in a shared language of critique, struggle, and hope to end various forms of human suffering".

\section{B. Critical Consciousness}

Critical consciousness is one of the important components of critical pedagogy and the key to people's freedom. There are three different levels of consciousness, namely 'semi-intransitive', 'naïve transitive', and 'critical' (Freire, 1970b). At the semi-intransitive consciousness level which is the lowest of the three, people tend to attribute their problems to super-natural sources or to their own incompetence and consequently will not do much to improve their conditions. The next level of consciousness is called 'naïve-transitive consciousness' which is one step closer to awareness. People who have naïve consciousness view the causes of their problems more accurately and begin to take action. The third level of consciousness which is the highest level of the three is 'critical consciousness'. People who manage to reach this level can analyze their existing problems more thoroughly and view reality and their life conditions as changeable phenomena. That is why they are able to engage in reflection and action, i.e. praxis.

\section{Critical Issues in ELT}

Despite the orchestrated efforts of many ELT scholars to depict English as a neutral, apolitical and irreligious language, there were gradual tendencies to view English as a language of western ideology with its associated hegemonic power of destruction. Many scholars gradually began to show overt pessimism about the role English is playing in the world and saw it as a vehicle used by some powerful countries in the world to transfer their thoughts, ideologies and social attitudes to the weaker nations of the world who have to learn their language. "Among foreign languages, English serves as a highway along which not only neutral messages but also thought, ideology, and social attitudes are transferred. English thus serves as a vehicle of what Phillipson (1992) called linguistic imperialism" (Neustupný and Nekvapil, 2003, pp.155-6).

All the above-mentioned concerns about the neutrality of the English language called for a critical reexamination of different aspects of ELT- a reexamination which could best be addressed through a critical pedagogic approach to ELT. 
Needless to say, of prime significance are the roles ELT educators are to assume in this regard. In Freirean pedagogy, teachers are no longer teaching technicians but scholars, researchers, cultural workers (Freire, 1998). As rightly mentioned by Byean (2011, p.5), being "aware of the interlinked facets of English and its underlying ideologies in ELT, English teachers need to approach ELT with more critical minds."

If "it is part of a teacher's responsibility to help students interrogate the hidden assumptions and values that accompany knowledge" (Canagarajah, 1999, p.16), the development of critical teachers should be a top priority in every educational program including TESOL.

\section{METHOD}

\section{A. Participants}

Forty three graduate students of TEFL studying at the Islamic Azad University, Mazandaran Science and Research Branch, participated in the present study. The participants were selected through convenient sampling as one of the researchers was the instructor of the 'Discourse Analysis' course the participants were taking. There were male and female students in both classes. In terms of general proficiency and other relevant background factors, the subjects were homogenous as they were all doing their MA in TEFL and were all classmates.

\section{B. Instrumentation}

In order to investigate the research hypothesis of the present study, the researchers used a five-point Likert-scale critical attitude questionnaire consisting of 24 items developed and validated in the context of Iran by Pishvaei and Kasaian (2013). The construct validity and content validity of the questionnaire had been established by the designers and the reported reliability was a high of .85 . As the subjects who participated in the validation process of the questionnaire were Iranian university students and professors, the researchers were convinced that the questionnaire could serve the purpose of the present research in Iran quite well. To further ensure the reliability of the questionnaire, it was administered to a group of 26 students with similar characteristics and the Cronbach Alpha index showed a high internal consistency, .81.

\section{Materials}

The materials used in the study were the book chapters on Discourse analysis the participants studied as the requirement of the course they were taking. This was used to familiarize them with the concept of discourse analysis in general and critical discourse analysis in particular. Maximum care was taken to ensure the sameness of the activities in both classes. The other materials that can be mentioned as relevant were the 'review of the related literature' section of the term projects the participants did under the supervision and the guidance of one of the researchers as the instructor of the course of Discourse analysis they were taking.

\section{Procedures}

In order to examine the possible influences of discourse analysis term-projects on critical attitudes of Iranian graduate students of TEFL, the participants of the study who were members of two intact MA classes were assigned to experimental and control groups.

The study was carried out in three phases. To begin with, all the participants in the two groups were given the attitude questionnaire as the pretest to assess the level of their critical attitudes before the treatment started. An independent sample t-test was run to check the required sameness of the two groups in terms of their initial critical attitudes. In the second phase, the students were asked to choose Critical Discourse Analysis (CDA) a Non-Critical Discourse Analysis (NCDA) topics for their term projects after consultation with the course instructor. The researchers made sure that half of the topics chosen by the students were related to 'Critical Discourse Analysis' and the other half simply about 'Discourse Analysis'. The students who had chosen the CDA topics constituted the experimental group while the rest of the students who had chosen NCDA topics made up the control group. Each group included both male and female students. The only distinguishing factor between the two groups was the nature of their term project topics (critical versus Non-critical). The participants were asked to do their term projects under the supervision of one of the two researchers (i.e., the course instructor) and interact with him regularly. In the third phase of the study, the subjects were given the same attitude questionnaire as the post-test in order to determine whether the subjects' critical attitudes had changed as a result of doing their term-projects.

After collecting the required data, the participants' scores obtained from their performance in the critical pedagogy questionnaire were put into two categories: acritical and critical. Scores ranging from 24 to 72 fell into the acritical category while the scores from 73 to 120 fell into the critical category. Since the assumption of the normality of the data was established, one sample and independent -sample t-tests were used.

\section{E. Design}

The present study had a quasi-experimental design as it involved experimental and control groups but used the convenience sampling.

\section{F. Data Analysis Procedure}


After collecting the pretest data from the participants which was collected to estimate their initial level of critical pedagogic attitudes and make sure that the two groups were not statistically significantly different from each other in terms of their attitudes, every participant was assigned a code and his/her responses to the questionnaire items were given values from 1 to 5 depending on whether and how much they agreed with the 24 statements in the questionnaire. As there were 24 items in the questionnaire and each item had between 1 and 5 points, the minimum and maximum scores were $24(24 \times 1)$ and $120(24 \times 5)$ respectively. Therefore, the researchers decided to set 72 which was equivalent to $50 \%$ of the maximum score a critical participant could possibly gain as the cut-off point to decide whether the participants had critical or no-critical attitudes. Independent-sample t-test was used to compare the scores obtained by the experimental and the control groups while a one sample-test was also run to see whether the groups were critical or acritical. Subsequent to the treatment and the placebo treatment, the posttest gain score of each participant was computed (gain score $=$ posttest score - pretest scores) to decide if the attitudes of the two groups had changed as a result of the treatment. Since the assumption of the normality of the data was established, the gain scores of the two groups were compared using independent sample t-test. To further investigate the participants' intragroup level of criticality, their scores were compared with the Test value of 72 (the cut-off point) using a one-sample t-test.

\section{RESULTS AND DisCUSSIONS}

\section{The Verification of the Null Hypothesis}

$\mathbf{H}_{\mathbf{O} 1}$ : Doing term projects on critical discourse analysis does not affect the Iranian graduate TEFL students' critical pedagogic attitudes.

To test the null hypothesis, the pretest data needed to be processed to find out the respondents' existing level of critical pedagogic attitudes and decide whether the two groups were statistically significantly different from each other in terms of their attitudes. To this end, every participant was given a code and his/her response to each questionnaire item was given values from 1 to 5 depending on which of the five likert scale questionnaire choice (Strongly disagree, Disagree, Neutral, Agree and Strongly agree) they had chosen. It is worth mentioning that in items 1, 3, 6, 7, 8, 12, 13, $15,18,20,21,22$ and 24 the highest level of criticality would be shown if the respondents selected Strongly Disagree. Items 2, 4, 5, 9, 10, 11, 14, 16, 17, 19 and 23 were the reverse items and in these items, the highest level of criticality would be shown by the choice of 'strongly agree'. The results of the latter items were reversed before tabulating the data. Therefore, 5 was regarded as the highest level of criticality in all items. As there were 24 items in the questionnaire and each item had between 1 and 5 points, the minimum and maximum scores were 24 and 120 respectively. Therefore, the researchers decided to set 72 which was equivalent to $50 \%$ of the maximum score a critical participant could possibly gain as the cut-off point above and below which the critical or no-critical groups. Then, as the assumption of normality of data was met, the one-sample t-test was used to compare the scores obtained by the experimental and the control groups.

TABLE 1:

ONE-SAMPLE STATISTICS

\begin{tabular}{|l|l|l|l|l|}
\hline & $\mathrm{N}$ & Mean & Std. Deviation & Std. Error Mean \\
\hline Experimental Group & 22 & 42.4545 & 8.51177 & 1.81472 \\
\hline Control Group & 21 & 43.9048 & 10.55891 & 2.30414 \\
\hline
\end{tabular}

TABLE 2:

ONE-SAMPLE TEST

\begin{tabular}{|l|l|l|l|l|l|l|}
\hline Test Value $=72$ & $\mathrm{t}$ & $\mathrm{df}$ & Sig. (2-tailed) & Mean Difference & \multicolumn{2}{|l|}{ 95\% Confidence Interval of the Difference } \\
\cline { 5 - 7 } & & & & & Lower & Upper \\
\hline Experimental Group & -16.281 & 21 & .000 & -29.54545 & -33.3194 & -25.7715 \\
\hline Control Group & -12.193 & 20 & .000 & -28.09524 & -32.9016 & -23.2889 \\
\hline
\end{tabular}

As Tables 1 and 2 above display, the mean scores of the experimental and control groups were 42.45 and 43.90 respectively both of which were well below the Test Value of 72. The sig values for the two groups were .000 signifying that the observed difference between the group mean and the Test value was statistically significant for both groups. In other words, neither the experimental nor the control group had a critical pedagogic attitude at the beginning of the program as their means were statistically significantly lower than the cut-off point, i.e. 72. Having established that both groups belonged to the acritical category, it was still necessary to make sure that the two groups were not meaningfully different from each other. To this end, the scores obtained by the participants in the two groups were subjected to an independent sample t-test whose results are included in Tables 3 and 4 below.

TABLE 3:

GROUP STATISTICS

\begin{tabular}{|l|l|l|l|l|}
\hline & $\mathrm{N}$ & Mean & Std. Deviation & Std. Error Mean \\
\hline Experimental & 22 & 42.4545 & 8.51177 & 1.81472 \\
\hline Control & 21 & 43.9048 & 10.55891 & 2.30414 \\
\hline
\end{tabular}


TABLE4:

INDEPENDENT SAMPLES TEST

\begin{tabular}{|c|c|c|c|c|c|c|c|c|c|}
\hline & \multicolumn{2}{|c|}{$\begin{array}{l}\text { Levene's Test for } \\
\text { Equality of Variances }\end{array}$} & \multicolumn{7}{|c|}{ t-test for Equality of Means } \\
\hline & \multirow[t]{2}{*}{ F } & \multirow[t]{2}{*}{ Sig. } & \multirow[t]{2}{*}{$\mathrm{t}$} & \multirow[t]{2}{*}{$\mathrm{df}$} & \multirow[t]{2}{*}{$\begin{array}{l}\text { Sig. (2- } \\
\text { tailed) }\end{array}$} & \multirow[t]{2}{*}{$\begin{array}{l}\text { Mean } \\
\text { Difference }\end{array}$} & \multirow[t]{2}{*}{$\begin{array}{l}\text { Std. Error } \\
\text { Difference }\end{array}$} & \multicolumn{2}{|c|}{$\begin{array}{l}\text { 95\% Confidence Interval of the } \\
\text { Difference }\end{array}$} \\
\hline & & & & & & & & Lower & Upper \\
\hline $\begin{array}{l}\text { Equal } \\
\text { variances } \\
\text { assumed }\end{array}$ & .528 & .472 & -.497 & 41 & .622 & -1.45022 & 2.91817 & -7.34357 & 4.44314 \\
\hline $\begin{array}{l}\text { Equal } \\
\text { variances } \\
\text { not } \\
\text { assumed }\end{array}$ & & & -.494 & 38.426 & .624 & -1.45022 & 2.93296 & -7.38552 & 4.48509 \\
\hline
\end{tabular}

A quick look at Tables 3 and 4 shows that the assumption of the equality of the means of the two groups was confirmed (Sig value $=.622$ ). After establishing the sameness of the experimental and control groups in terms of their initial critical pedagogic attitudes, the researchers needed to examine the possible effects of treatment and placebo treatment on the experimental and control groups respectively. Therefore, the posttest gain scores of all participants in the two groups were computed by subtracting the pretest score from the posttest score of each individual and then compared through an independent sample t-test. Tables 5 and 6 below show the details.

TABLE 5:

GAIN SCORE GROUP STATISTICS

\begin{tabular}{|l|l|l|l|l|}
\multicolumn{1}{c}{ GAIN SCORE GROUP STATISTICS } \\
\begin{tabular}{|l|l|l|l|l|}
\hline & Mean & Std. Deviation & Std. Error Mean \\
\hline Experimental Group & 22 & 29.6364 & 8.80771 & 1.87781 \\
\hline Control Group & 21 & 10.0952 & 8.67124 & 1.89222 \\
\hline
\end{tabular}
\end{tabular}

TABLE 6:

GAIN SCORE INDEPENDENT SAMPLES TEST

\begin{tabular}{|c|c|c|c|c|c|c|c|c|c|}
\hline & \multicolumn{2}{|c|}{$\begin{array}{l}\text { Levene's Test for Equality } \\
\text { of Variances }\end{array}$} & \multicolumn{7}{|c|}{ t-test for Equality of Means } \\
\hline & \multirow[t]{2}{*}{$\mathrm{F}$} & \multirow[t]{2}{*}{ Sig. } & \multirow[t]{2}{*}{$\mathrm{t}$} & \multirow[t]{2}{*}{$\mathrm{df}$} & \multirow[t]{2}{*}{$\begin{array}{l}\text { Sig. (2- } \\
\text { tailed) }\end{array}$} & \multirow[t]{2}{*}{$\begin{array}{l}\text { Mean } \\
\text { Difference }\end{array}$} & \multirow[t]{2}{*}{$\begin{array}{l}\text { Std. Error } \\
\text { Difference }\end{array}$} & \multicolumn{2}{|c|}{$\begin{array}{l}\text { 95\% Confidence Interval of } \\
\text { the Difference }\end{array}$} \\
\hline & & & & & & & & Lower & Upper \\
\hline $\begin{array}{l}\text { Equal variances } \\
\text { assumed }\end{array}$ & .112 & .740 & 7.327 & 41 & .000 & 19.54113 & 2.66683 & 14.15536 & 24.92689 \\
\hline $\begin{array}{l}\text { Equal variances } \\
\text { not assumed }\end{array}$ & & & 7.330 & 40.958 & .000 & 19.54113 & 2.66583 & 14.15720 & 24.92505 \\
\hline
\end{tabular}

Table 5 shows that the mean of gain scores of the experimental group was 29.63 which was almost three times bigger than the control groups' gain score mean of 10.09. This was indicative of the effectiveness of the treatment given to the experimental group. Moreover, the sig value of .000 in Table 6 confirms the statistical significance of the improvement in the experimental group. This is enough to reject the null hypothesis which had assumed no effect for doing critical discourse analysis research projects on the critical pedagogic attitude of Iranian graduate students of TEFL.

Although the comparison made between the gain scores of the two groups served to reject the null hypothesis, the researchers considered it worthwhile to compare the mean of each group with the Test Value of 72 to see whether the observed gains in the two groups had helped them reach the threshold level of criticality or not. Tables 7 and 8 include SPSS output for poet-test one sample statistics and posttest one sample test.

TABLE 7:

POSTTEST ONE-SAMPLE STATISTICS

\begin{tabular}{|l|l|l|l|l|}
\hline & $\mathrm{N}$ & Mean & Std. Deviation & Std. Error Mean \\
\hline Experimental Group & 22 & 72.0909 & 9.90867 & 2.11254 \\
\hline Control Group & 21 & 54.0000 & 10.91329 & 2.38148 \\
\hline
\end{tabular}

TABLE 8:

POSTTEST ONE-SAMPLE TEST

\begin{tabular}{|l|l|l|l|l|l|l|}
\hline & \multicolumn{2}{|l|}{ Test Value $=72$} & \multicolumn{2}{l|}{} \\
\cline { 2 - 7 } & $\mathrm{t}$ & $\mathrm{df}$ & Sig. (2-tailed) & Mean Difference & \multicolumn{2}{l|}{ 95\% Confidence Interval of the Difference } \\
\cline { 3 - 7 } & & 21 & .966 & .09091 & Lower & Upper \\
\hline Experimental Group & .043 & 20 & .000 & -18.00000 & -22.9677 & -13.0323 \\
\hline Control Group & -7.558 & &
\end{tabular}

As it is evident in Table 7, the control group improved its mean from the initial 43.90 to 54. This improvement which can, in all probabilities, be attributed to the instructions they had received in the course about the principles of critical pedagogy was not large enough to make them members of the critical group (above 72). In the case of the experimental group, however, the treatment was effective enough to change the participants' group membership from their initial 
acritical group membership to the critical one. This can be confirmed both by the magnitude of their mean which was larger than the cut-off value of 72 and the sig value of .966 which confirms the equality of the gained mean score and set Test value.

\section{CONCLUSIONS AND IMPLICATIONS}

In view of the fact that despite its international relevance and coverage, English language teaching industry is still monopolized by a few native speaking countries who fail to fully appreciate the implications of English as an international language, the training and development of truly critical English language teachers can to some extent ward off the hegemony of native speaker-controlled ELT industry. If education is to serve a worthwhile purpose, it should be helping the students move from Freire's (1970b) first level of consciousness (semi-intransitive) to its third level (critical consciousness). This cannot happen unless the teachers have reached the third level of consciousness themselves. For EFL teachers in many 'expanding circle countries' who have to teach imported textbooks which are generally laden with western ideologies, this third level of consciousness is even a more basic necessity. This study was an attempt to investigate the effect of assigning term projects on critical discourse analysis on Iranian graduate students' critical attitudes. The important findings of this study can be summarized below.

1. The graduate students of TEFL as prospective teachers of English as a foreign language did not have any critical attitudes towards the hegemonic potentials of ELT industry.

2. As the small improvement in the critical attitudes of the control group of the present study showed, the teaching of the principles of critical discourse analysis as a part of discourse analysis course cannot be effective enough to make the graduate students of TEFL critical.

3. The assignment of the term projects on critical discourse analysis greatly improved the critical attitudes of the Iranian graduate students of TEFL so much so that their initial acritical attitude changed into a critical one.

The third finding is in complete agreement with Freire's (1970, p. 126) argument that social transformation can take place if individuals become engaged in 'praxis' or informed action.

What can be said about the above conclusions is that an important concern such as the development of the critical attitude of the prospective EFL teachers should not be left to the accidental changes that might be brought about by covering a few chapters on critical discourse analysis. Rather, it should be based on taking informed action. The present study proved that doing CDA term projects can efficiently improve the critical attitudes of the Iranian prospective EFL teachers. Other strategies that can be deemed effective are the inclusion of a two-unit course on critical pedagogy in TEFL BA and MA programs or setting up seminars and workshops on critical pedagogy. MA theses on critical discourse analysis and critical pedagogy can also prove helpful. Therefore, one implication of the present study is that MA candidates are encouraged to do their MA theses on critical pedagogy or critical discourse analysis.

If we expect critical actions out of the would-be teachers of English as a foreign language, we have no choice but to help them reach what Freire (1970b) called 'critical consciousness which is best possible through praxis.

\section{RECOMMENDATIONS FOR FURTHER RESEARCH}

The followings are some suggestions for further research that can be done in the area of critical pedagogy:

Further studies can be done with larger samples selected from many more universities.

Similar studies can be done with practicing high school and private institute language teachers whose critical consciousness is more urgently required than that of prospective English teachers.

Another useful research work is to compare the critical attitudes of MA graduates in TEFL whose theses involved the investigation of critical pedagogy issues with those graduates whose theses were irrelevant to critical pedagogy.

\section{REFERENCES}

[1] Byean, H. (2011). An Exploration for Glocalizing Critical Pedagogy in the Korean Middle School Context: Toward Critical Co-teaching Praxis between Local and Native-English-Speaking Teachers. Unpublished doctoral dissertation, University of Wisconsin-River Falls-River Falls.

[2] Brookfield, S.D. (1987). Developing critical thinkers. San Francisco, CA: Josey Bass.

[3] Burbules, N. \& R. Berk. (1999). Critical thinking and critical pedagogy: Relations, differences, and limits. In T. Pop kewitz \& L. Fendler (eds.), Critical theories in education. New York: Routledge, pp.1-13.

[4] Canagarajah, A. S. (1999). Resisting Linguistic Imperialism in English Teaching. Oxford: Oxford University Press.

[5] Fisher, A. \& M. Scriven. (1997). Critical thinking: Its Definition and assessment: Norwich, UK: Centre For Research In Critical Thinking, University of East Anglia.

[6] Freire, P. \& D. Macedo. (1987). Literacy: Reading the Word and the World. South Hadley, MA: Bergin \& Garvey Publishers.

[7] Freire, P. (1970). Cultural action and Conscientization. Harvard Educational Review, 40(3), 452-477.

[8] Friere, P. (1998). The Adult Literacy Process as Cultural Action for Freedom. Harvard Educational Review, 68(4), 480-498.

[9] Giroux, H. (1983). Theory and resistance in education: A pedagogy for the opposition. New York: Bergin \& Garvey publishers.

[10] Horkheimer, M. (1982). Critical Theory. New York: Seabury Press.

[11] Kanpol, B. (1999). Critical pedagogy: An introduction (2nd ed.). Westport, CT: Bergin \& Garvey publishers. 
[12] Kellner, D. (2000). Multiple literacies and critical pedagogies: New paradigms. In P. Trifonas (Ed.), Revolutionary Pedagogies: Cultural Politics, Instituting Education, and the Discourse of Theory. New York: Routledge, pp.196-221.

[13] Kumaravadivelu, B. (2006). TESOL methods: changing tracks, challenging trends. TESOL Quarterly, 40(1), pp.59-81.

[14] McLaren, P. \& J. Kincheloe, (Eds.). (2007). Critical pedagogy: Where Are We Now? New York: Peter Lang.

[15] Neustupný J.V. and J. Nekvapil. (2003). Language management in the Czech Republic. Current Issues in Language Planning 4(3-4), 181-366.

[16] Pennycook, A. (1989). The concept of method, interested knowledge, and the politics of language teaching. TESOL Quarterly 23, 589-618.

[17] Phillipson, R. (1992). Linguistic imperialism. Oxford: OUP.

[18] [18] Pishvaei, V. \& S. A. Kasaian. (2013). Design, Construction, and Validation of a Critical Pedagogy Attitude Questionnaire in Iran. European Online Journal of Natural and Social Sciences, 2(2s), pp. 59-74. http://europeanscience.com/eojnss/article/view/141_(accessed 29/12/2013).

[19] Scriven, M. \& R. Paul. (1996). Defining critical thinking: a draft statement for the national council for excellent in critical thinking. http://www.critical thinking .org_/ university/univclass / defining .Html (accessed 20/10/2013).

Shaban Barimani Varani was born in Iran in 1956. He received a Ph.D. in TEFL (Teaching English as a Foreign Language) from Mysore University in 2009 in India, an M.A. in TEFL (Teaching English as a Foreign Language) from Islamic Azad University in Iran, in 2001, and a B.A. in TEFL from UTE (University for Teacher Education) in Tehran, Iran in 1989. As for his professional background, he is the chairman of the EFL department at Islamic Azad University, Sari Branch since 2009 up to now and a member of the faculty member of English Language and Linguistics in Islamic Azad University, Sari Branch since 2002. Now, as chairman in TEFL and Linguistics and as an associate professor, he runs courses in Linguistics, Research, Testing, and methodology in Sari and Mazandaran Research and Technology branches of Islamic Azad University at the levels of BA and MA.

Seyed Ahmad Kasaian is an assistant professor at the department of English, Dr. Shariati campus, Farhangian University, Mazandaran, Iran. He has years of experience in foreign language teacher education. His research interests are Critical Discourse Analysis, Critical Pedagogy, and Teacher development. 